\title{
RESPONSES OF SKIN AND COAT FIBRES IN BARKI EWES TO THE NUTRITION ON SALT PLANTS AND PROPIONIBACTERIAUNDER THE ARID CONDITIONS
}

\author{
A.S. Abdou, S.A. Hekal, N.S. Badawy and W.A. Ramadan
}

Department of Wool Production and Technology, Desert Research Center, El-Mataryia, Cairo, Egypt

\section{SUMMARY}

The present study aimed at investigating the effect of using Barki sheep ewes. Forty-two animals were utilized in the experiment. 14 ewes served as control (given berseem hay as a basal roughage diet), 14 ewes were designed to be given mixture of salt plants at a percentage of (50\% Atriplex Halimus and Nummularia and $50 \%$ Pearl Millet) and 14 ewes were fed the same diet with propionibacteria (1gm/h/day). Skin samples were taken from different feed trials and prepared for histological and histochemical studies. Wool fibre samples were also examined illustrating some wool traits under the same different feeding treatments. Results indicated a significant enhancement of the follicle activity due to the follicle dimensions, primary follicles exhibited less reaction than secondary follicles $(P<0.05)$. The addition of propionibacteria decreased disturbances caused by salt plants on follicle dimensions. It also enhanced $(P<0.05)$ the production of protein contents in both primary and secondary wool follicle sheathes. There were no differences in carbohydrate contents in the wool follicles of animals in the control group and those fed propionibacteria. Administration of propionibacteria resulted in an increased fibre diameter and wool traits. In conclusion, giving Barki ewes propionibacteria as feed additive enhanced the metabolic activity resulting in an increased wool follicle activity and decreased the negative effect of salt plants on their performance.

\section{Keywords: Propionibacteria supplementation, salt plants, wool follicle activity, wool traits, Barki ewes}

\section{INTRODUCTION}

Salinity is a global problem worldwide in particular in arid and semiarid zones. Several investigators concluded that cultivation of salt and drought tolerant shrubs, grasses and legumes may be consider the appropriate solutions for filling the gabs of feed deficiency in these regions (El-Shaer, 2006 and Hanafy et al., 2007). The cultivation of salttolerant crops or halophytes on saline soil has significant social and economic potential that needs to be further explore and developed. It is a target to achieve how to prevent salinification and produce economic fodder crops to overcome the problems of feed shortage and high feeding costs.

Supplementing saltbush with carbohydrate sources can improve its feeding value by providing energy to ruminal microbes to produce microbial protein, stimulate carbohydrate digestion and detoxify secondary compounds (Al-Owaimer et al., 2011).

Ruminally derived propionate is the major precursor for gluconeogenesis (Reynolds et al., 2003), theoretical efficiency of propionate as a source of energy in the form of ATP is $109 \%$ compared with glucose (Mc Donald et al., 1987). They also stated that the efficiency of utilization for maintenance of propionic acid is 0.86 versus 0.59 for acetate and 0.76 for butyrate, thus, increasing ruminal synthesis of propionate may increase glucose supply, reduce ketosis, and provide increased substrate for lactose.

Supplemental direct-fed microbial such as propionibacteria may increase the molar proportion of ruminalpropionate, reduce rumen acidosis, and increase hepatic gluconeogenesis when fed to ruminants (Stein et al., 2006).

Propionibacteria are natural inhabitants of the rumen that make up $1.4 \%$ of ruminal microflora and produce propionate, a major precursor for glucose production by hepatic gluconeogenesis and thus direct feeding of propionibacteria may be a natural way to increase hepatic glucose production and positively influence metabolism (Francisco et al., 2002). Inclusion of propionibacteria 169 (P 169) in the diet increased concentrations of glucose and insulin in plasma but not influence reproduction of lactating dairy cows (Aleman et al., 2007 and Stein et al., 2006). Also, propionibacteria have the ability to convert lactic acid and glucose to acetic and propionic acid and reduce the risk of acidosis (Ghorbani et al., 2002) and increase weight gain (Yoon and Stern, 1995).

The high salt loads for sheep possibly bring a series of negative impact, including reducing the efficiency of energy use for production (Arieli et al., 1989), voluntary feed intake (Blache et al., 2007) and productivity (Warner and Casson, 1992). The impact of nutrition on the wool growth of sheep has long been considered. Correlation between feeding and sheep wool growth as well as other forms of animal production has been widely dealt with. Differences in substrates supply which represent an essential factor for fibre synthesis of the wool follicles (unit of wool production) reflect clearly the effect of nutrient intake and wool output. 
Therefore, the present study was design to detect the histological, histochemical changes and growth activity of different skin components of sheep under different feeding treatments and aimed to investigate the effect of nutritional factors on the characters and rate of growth of both fibre follicles and their fleeces.

\section{MATERIALS AND METHODS}

The study was carried out in the Experimental Station of Desert Research Center, located at RasSuder region, Southern Sinai Governate, Egypt that is characterized by high salt affected saline resources (soil and ground water). The study had performed along 9 months beginning from October (2013). 42 adult Barki ewes, averaged 2-3 years old and about $35 \mathrm{Kg}$ body weight, were assigned to dietary treatments salt plants, propionibacteria 169 (p 169) and control. The propionibacteria-freudenreichii strain 169 (Dairy Pro P 169) is a dried material of viable bacteria prepared by Bio-Vet Inc. USA., contains a live bacterial count: 30 Billion $\left(3 \times 10^{10}\right)$ Colony Forming Units (CFU). The additive was kept frozen at $\left(-20^{\circ} \mathrm{C}\right)$ as recommended until feeding. Live bacterial numbers of product was been enumerated with specie specificity for genus $P$. freudenreichii before feeding. Direct fed Microbial (DFM) package was been analyzed for total counts of propionibacteria according to Vedamuthu and Reinbold (1967).

The animals were equally assigned randomly in three groups (14 in each one) where all animals in each group were supplemented daily by $40 \%$ of their diets concentrate feed mixture which contains $25 \%$ cotton seeds cake, 35\% yellow corn, 30\% wheat bran, $3 \%$ rice bran, $3 \%$ molasses, $1 \%$ urea, $2 \%$ limestone and $1 \%$ common salt. The first group representing the control $(\mathrm{C})$ was given berseem hay (Trifulium Alexandrinum) as a basal roughage diet, while the second group (S) was offered mixture of salt plants at a percentage of (50\% Atriplex Halimus and Nummularia and 50\% Pearl Millet). The third group (P) had the same mixture supplemented with propionibacteria 169 (P 169) as feed additive $(1 \mathrm{~g} /$ head/day). The animals were offering their daily rations according to their live body weight calculated from the nutritional requirements according to Kearl (1982). All animals were given the energy diets at $40 \%$ of their maintenance requirements while roughage was given $60 \%$. Drinking water was available twice daily.

Skin biopsy samples were been taken at different feed trials from the mid-side position and fixed in calcium formol for about 24 hours (Barker, 1958), washed and left for 24 hours in distilled water and transferred to $70 \%$ ethanol then dehydrated, cleared and embedded in paraffin wax. Sections of $6-8 \mu \mathrm{m}$ thickness were cut and stained with Haematoxylin and Eosin (Drury and Wallington, 1980). The histological measurements included the average external and internal diameters of both primary and secondary follicles and the follicle wall thickness was calculated. Histochemically, Periodic acid Schiff's reaction (Mc-Manus and Cason, 1950) was used for detecting carbohydrates as red color and Mercury bromophenol blue (Chapman, 1975) was used for the demonstration of general proteins as represented by the blue color.

Wool samples were taken at the end of the nutritional trial from $10 \mathrm{~cm}^{2}$ patch of left clipped mid-side position as close as possible to the skin surface. Samples were weighed to measure greasy wool production then kept in plastic bags for further analysis. Ten staples were taken randomly from each wool samples to measure staple length to the nearest $\mathrm{mm}$ using a ruler. Length measured from the bottom until the dense part of the staple. Clean scoured yield was calculated using the method suggested by Chapman (1960). Five hundred fibres from each sample were used to estimate the average fibre diameter and its distribution percentage.

The histological, histochemical and fibre diameter measurements were undertaken by using an image analyzer software (Zen, 2012, Blue edition) and device (Carl-Zeiss Micro Imaging $\mathrm{G}$ and $\mathrm{bH}$ ) with lenses 10/0.847 and 40/0.65.

Data were statistically analyzed by SAS (2004) using general linear model procedure (GLM) classification, followed by Duncan Multiple Range Test to examine the significance between means.

\section{RESULTS AND DISCUSSION}

The development of feeding strategies for fibreproducing animals requires consideration of the basic biology of fibre production in addition to awareness of changes in physiological state. Provision of dietary nutrients may expected to influence fibre growth indirectly by altering concentrations of circulating hormones and numbers and receptivity of cellular receptors or directly by providing components for cellular and extra-cellular structure, oxidisable energy or catalysis in the follicle system.

Homeostatic considerations and those associated with genetically determined partition of absorbed and circulating nutrients (including competition between other integumental and non-integumental tissues) are also, being expected to apply. Such direct or indirect influences particularly in the context of fluctuating nutrient supply may modulate the behavior of the hair follicle cycle and alter fibre production by increasing rate of matrix cell proliferation and /or post-mitotic hypertrophy in anagen follicles.

Histologically, the vertical differentiation of the wool follicle was composed of several zones. The bulb, the zone of active cell division, the keratogenous zone in which the elongation of cells takes place (Fig. 1) and the final zone in which the follicle glands (sebaceous and sweat) open (Fig. 2). From the outermost aspect of the follicle the histological structures are: the outer root sheath consisting of several cell layers and the innermost adjacent to the inner root sheath is called the companion layer (Fig. 1). 


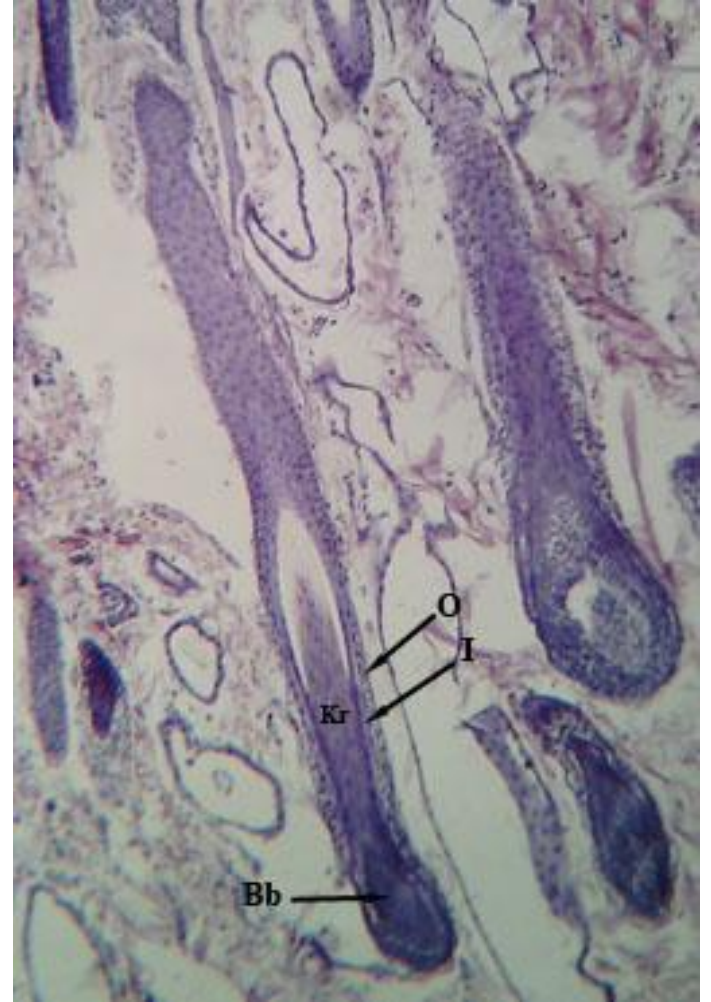

Figure 1. Longitudinal section in the wool follicle of Barki ewes showing its different zones. Bb, Bulb; Kr, Keratogenons Zone; I, Inner root sheath; O, Outer root sheath. (HX.E., X40)

The use of feed additives (propionibacteria) and salt plants in sheep nutrition showed a significant effect on the wool follicle dimensions which might mean affecting its activity. The changes in the external and internal diameters and wall thickness of both primary and secondary wool follicles were demonstrated in Table (1) and Figure (3).

Significant differences occurred between the experimental groups, where the (S) group showed the lowest $(\mathrm{P}<0.05)$ dimensions of primary follicle $(139.71 \pm 5.25 \mu \mathrm{m}$ external diameter and $67.85 \pm 3.45 \mu \mathrm{m}$ internal diameter) as shown in Table (1). The usage of propionibacteria in group (P) increased $\quad(\mathrm{P}<0.05)$ the external diameter

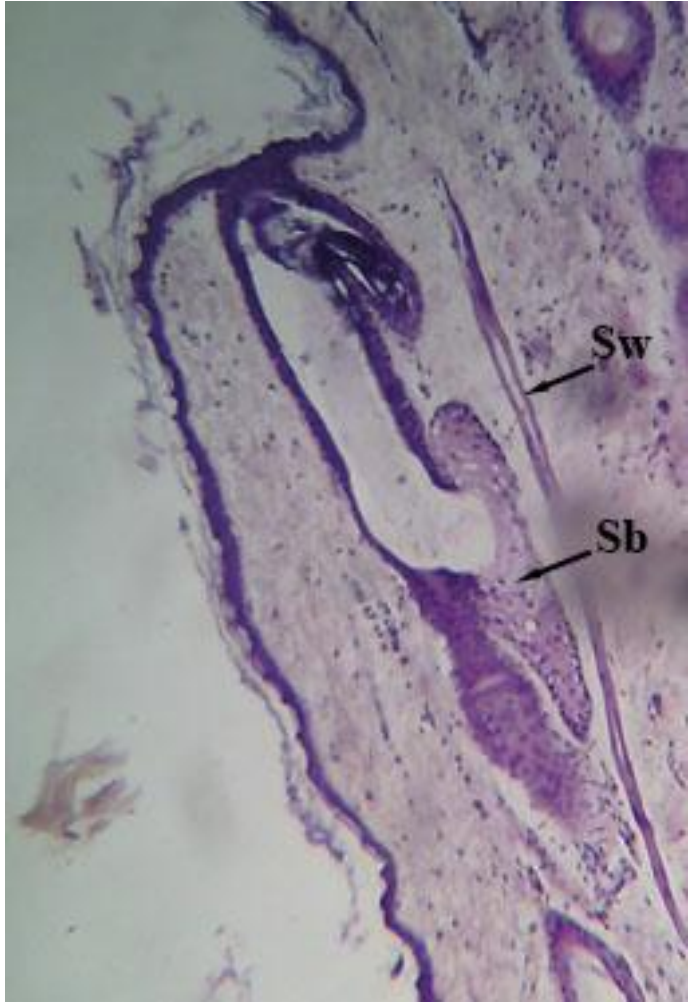

Figure 2. Vertical section in the skin of Barki ewes showing longitudinally upper zone of wool follicle with sweat gland duct $(\mathrm{Sw})$ and sebaceous gland (Sb). (HX. E., X 40)

$(155.88 \pm 4.67)$ and non-significantly the internal diameter $(63.91 \pm 3.07 \mu \mathrm{m})$ of the primary follicles. Concerning wall thickness of the primary follicles, significant the animals of control group showed higher values (C) $(95.92 \pm 3.11 \mu \mathrm{m})$ followed by $(\mathrm{P})$ group $(91.97 \pm 3.18 \mu \mathrm{m})$ while group $(\mathrm{S})$ had the lowest values $(71.86 \pm 3.57 \mu \mathrm{m})$ (Table, 1$)$.

These results of primary follicle dimensions demonstrated that the feeding salt plants and administration of propionibacteria increased at a limit the size and activity of the primary follicles, which would reflected on wool production. Adding salt plants only to the diet was of negative effect (Fig. 3).

Table 1. Mean values $( \pm \mathrm{SE})$ of external and internal diameters and wall thickness of both primary and secondary wool follicles in the skin of Barki ewes under different feeding treatments

\begin{tabular}{lccc}
\hline Follicle dimensions & Feeding treatments & Primary follicle & Secondary follicle \\
\hline \multirow{2}{*}{ External diameter $(\boldsymbol{\mu m})$} & $\mathbf{C}$ & $169.01 \pm 4.58^{\mathrm{a}}$ & $79.67 \pm 2.69^{\mathrm{ab}}$ \\
& $\mathbf{S}$ & $139.71 \pm 5.25^{\mathrm{c}}$ & $75.35 \pm 2.08^{\mathrm{b}}$ \\
& $\mathbf{P}$ & $155.88 \pm 4.67^{\mathrm{b}}$ & $84.20 \pm 2.38^{\mathrm{a}}$ \\
\hline \multirow{3}{*}{ Internal diameter $(\boldsymbol{\mu m})$} & $\mathbf{C}$ & $73.09 \pm 3.01^{\mathrm{a}}$ & $29.29 \pm 1.15^{\mathrm{b}}$ \\
& $\mathbf{S}$ & $67.85 \pm 3.45^{\mathrm{ab}}$ & $24.06 \pm 0.89^{\mathrm{c}}$ \\
& $\mathbf{P}$ & $63.91 \pm 3.07^{\mathrm{b}}$ & $34.05 \pm 1.01^{\mathrm{a}}$ \\
\hline & $\mathbf{C}$ & $95.92 \pm 3.11^{\mathrm{a}}$ & $50.38 \pm 2.17^{\mathrm{a}}$ \\
& $\mathbf{S}$ & $71.86 \pm 3.57^{\mathrm{b}}$ & $51.29 \pm 1.68^{\mathrm{a}}$ \\
\hline
\end{tabular}

C, control; S, salt plants; $\mathrm{P}$, propionibacteria.

In each parameter, means within the same column followed by different letters differed significantly $(\mathrm{P}<0.05)$. 

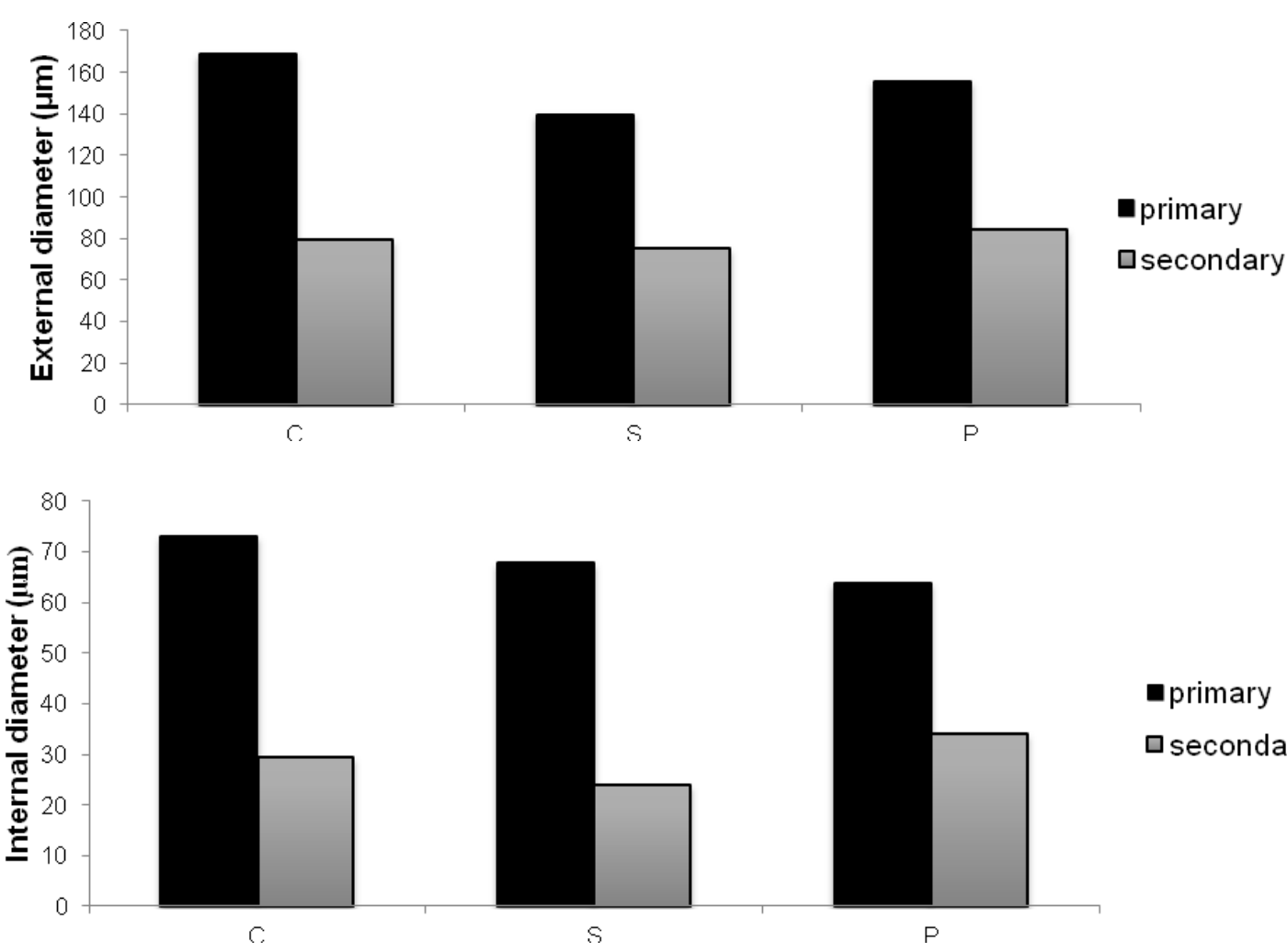

- primary

口secondary

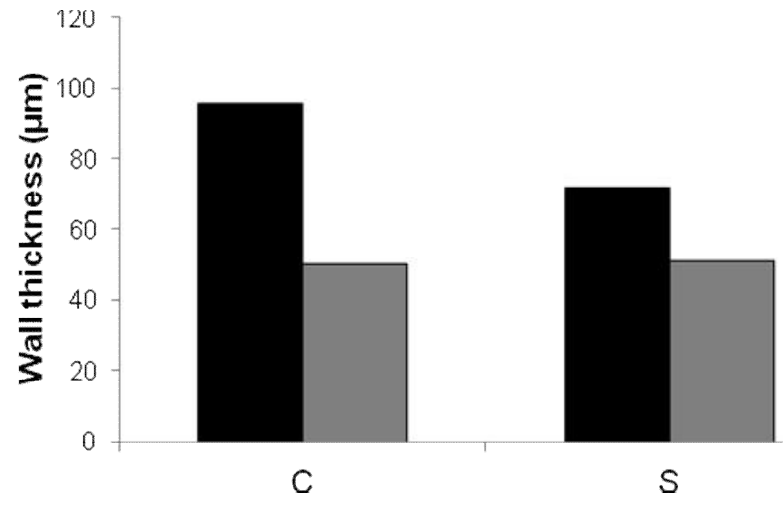

primary

asecondary

Figure 3. The external and internal diameters and wall thickness of primary and secondary wool follicles in the skin of Barki ewes under different feeding treatments. $C$, control; $S$, salt plants; $P$, propionibacteria

The results of secondary follicles in Table (1) showed a greatest benefit of propionibacteria represented as a significant increase in the values of the external $(84.20 \pm 2.38 \mu \mathrm{m})$ and internal $(34.05 \pm 1.01 \mu \mathrm{m})$ diameters which exceeded the values of the control group $(79.67 \pm 2.69 \mu \mathrm{m}$ and $29.29 \pm 1.15 \mu \mathrm{m})$ respectively. Wall thickness of secondary follicles had no significant difference in relation to different feeding treatments (Fig. 3).

Abdelaziz et al. (2000) stated that wool growth fluctuated with varying levels of nutrition and this was seen in variations in length and diameter of the wool fibres. Thus, the intake of energy and protein above that required for the maintenance led to the formation of body protein and enhancement of wool production. Wool growth can only take place if the necessary precursor materials which supplied to the follicles and both nutrition and metabolic rate may limit this. In another studies by Cottle (1988), Rafat and Shodja (2004) follicle activity were affected by the level of energy and protein in diets. In the present study, animals fed salt plants showed a significant decrease in all primary and secondary follicles dimensions reflecting some causes of the problems represented in the anti-nutritional factors like Tannins, Saponin and Flavonoids and the reduction in crude protein and organic matter in this plants. The use of propionibacteria improved the primary follicle dimensions and largely the secondary ones. These dimensions increments might been attributed to the increase in feed utilization efficiency. In agreement, Abdel-Salam et al. (2014) stated that Synbiotic supplementation orally might enhance the feed efficiency of lambs. Russell and Wilson (1996) reported that response of lambs to probiotic supplementation might be due to improving fibre degradation. Higher consumption and higher feed utilization was been shown as a result to adding 
probiotic (Antunovic et al., 2006). Sarwar et al. (2010) found that probiotic supplementation improved weight gain of growing lambs. In addition, Khalid et al. (2011) reported that lambs fed diets with probiotic had improved weight gain and they pointed out that improving might be depending upon probiotic rate or level. Also, the inclusion of propionibacteria in the diet increased the molar proportion of propionate in rumen fluids, which might support the follicle growth rate and activities. In addition, the increase in follicle dimensions in the group (P) could be histologically attributed to the morphological changes in the connective tissue sheath which accompanied that the follicles during the activity periods (Montagna and Ellis, 1958). They added that during activity, the outer root sheath showed an increase in its thickness due to large number of cell layers leading to be relatively layer fibres. Mahgoubet al. (1974) stated that the relation between both size and activity of the follicles was mostly quantitative. They demonstrated that in case of inner root sheath the only difference between small and large follicles seemed to be in the size of the cells of Henle's and Huxley's layers and the inner root sheath cuticle.

The energy and protein contents are important quality index of diets in animal nutrition. The present study indicated that the presence of propionates in the diet is associated with an apparent improvement in carbohydrate tolerance. The carbohydrates are considered as the sign of follicle activity according to the assumption of Montagna (1956) that the carbohydrates in the outer root sheath is the source of energy for protein synthesis during fibre growth. In this study, the presence of carbohydrates in both primary and secondary follicles (Figs. 4 and 5) showed an increased values in (S) group followed by both (C) and (P) groups in primary follicles (Table $2)$, whereas the lowest concentration of carbohydrates was found in (P) group in the secondary follicles. Antunovic et al. (2006) pointed out that weaned lambs fed diet with $1 \%$ probiotics had lower glucose concentration and they explained this result to higher fibre digestion leading to more production of ketogenic moieties. The same authors reported that adding probiotic to diet resulted in increasing bacterial count, which leads to produce protein by bacteria. On the other hand, the inclusion of synbiotic to the fructose oligosaccharides (FOS), terpenoids, saponins, tannins, alkaloids and dietary fibres make them ready to be metabolized in the rumen media of lambs and could enhance the production of volatile fatty acids which are of first priority for the animals as a source of energy absorbed from the ruminal mucosa (Al-Sobayil et al., 2008 and Abdel-Salam et al., 2014). Mannus and Boda (1965) stated that propionate was been documented to be gluconeogenetic in ruminants. However, a recent publication showed decrease fasting serum glucose and reduced maximum insulin increments during glucose-tolerance tests after the consumption of sodium propionate. Also, Todesco et al. (1991) concluded that sodium propionate reduces the postprandial glucose response and these are also longer-term effects on carbohydrate metabolism resulting in improved glucose tolerance, which may result from adaptation in the absorptive capacity.

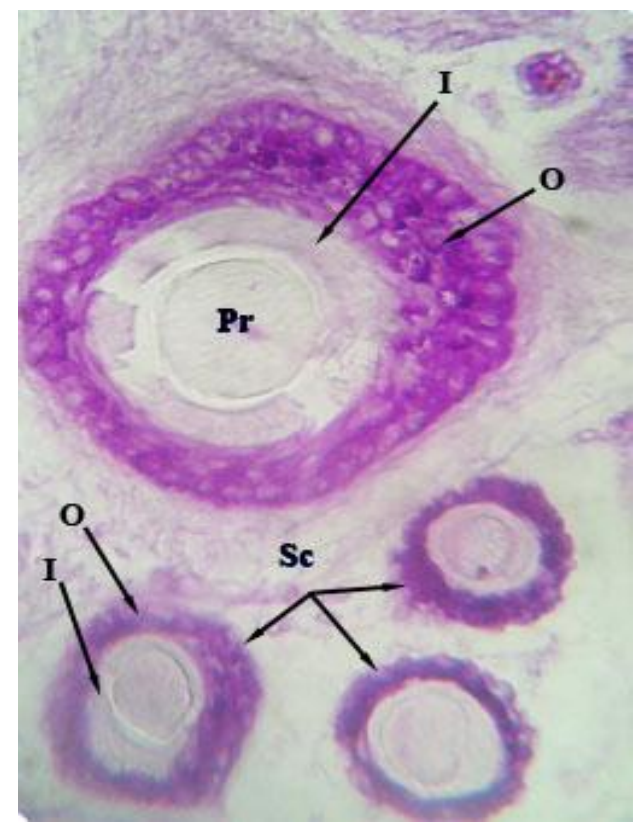

Figure 4. Transverse section in the wool follicles of Barki ewes stained with PAS method showing the distribution of general carbohydrates in the different follicle sheaths. I, inner root sheath; $O$, outer root sheath; Pr, primary follicle; Sc, secondary follicle (X400) 


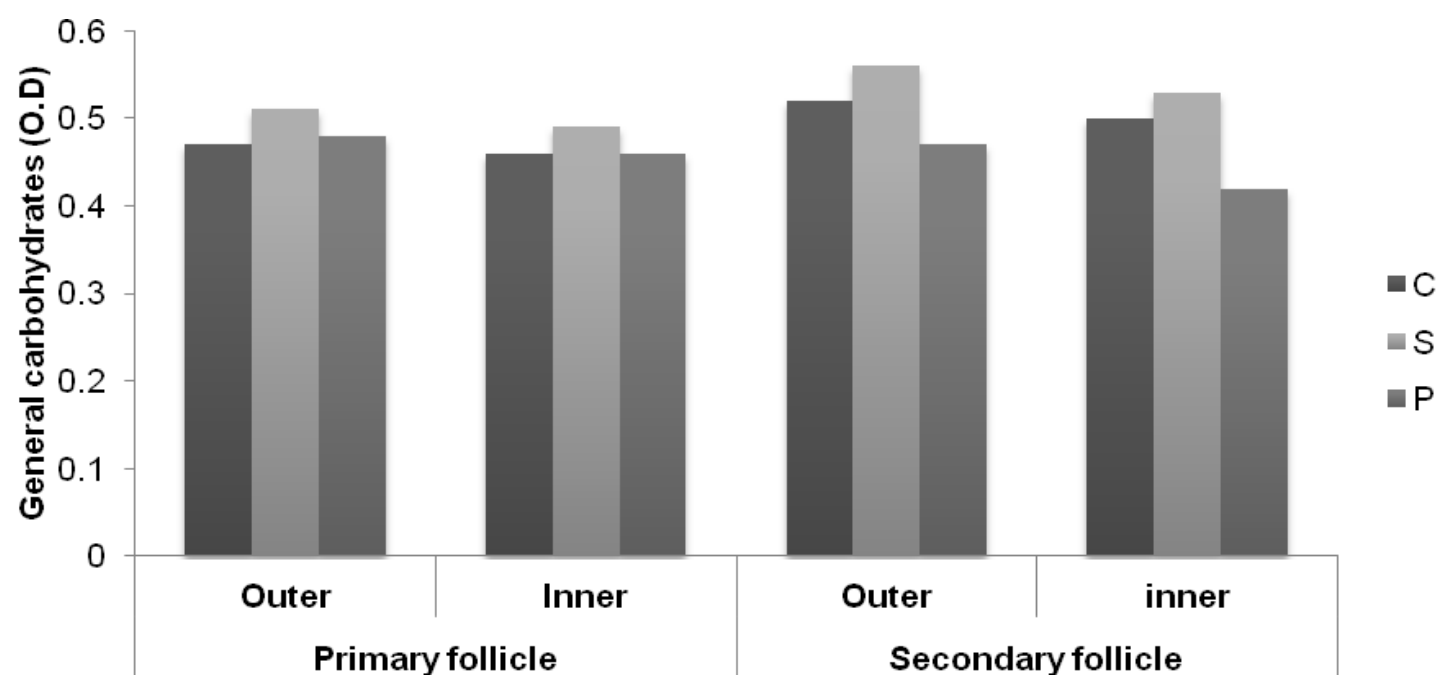

Figure 5. Average optical density values of general carbohydrates in the outer and inner root sheaths of both primary and secondary follicles in the skin of Barki ewes under different feeding treatments. C, control; $S$, salt plants; $P$, propionibacteria

Table 2. Mean optical density values $( \pm$ SE) of different histochemical reactions in the wool follicle sheaths of Barki ewes under different feeding treatments

\begin{tabular}{lccccc}
\hline Histochemical & feeding & \multicolumn{2}{c}{ Primary follicle } & \multicolumn{2}{c}{ Secondary follicle } \\
\cline { 3 - 6 } parameters & treatments & O. r. sh & I. r. sh & O. r. sh & I. r. sh \\
\hline \multirow{2}{*}{ Carbohydrate } & $\mathbf{C}$ & $0.47 \pm 0.007^{\mathrm{b}}$ & $0.46 \pm 0.005^{\mathrm{b}}$ & $0.52 \pm 0.007^{\mathrm{b}}$ & $0.50 \pm 0.006^{\mathrm{b}}$ \\
substances & $\mathbf{S}$ & $0.51 \pm 0.007^{\mathrm{a}}$ & $0.49 \pm 0.005^{\mathrm{a}}$ & $0.56 \pm 0.007^{\mathrm{a}}$ & $0.53^{ \pm} 0.006^{\mathrm{a}}$ \\
& $\mathbf{P}$ & $0.48 \pm 0.007^{\mathrm{b}}$ & $0.46 \pm 0.005^{\mathrm{b}}$ & $0.47 \pm 0.007^{\mathrm{c}}$ & $0.42 \pm 0.006^{\mathrm{c}}$ \\
\hline \multirow{3}{*}{ General proteins } & $\mathbf{C}$ & $0.50 \pm 0.010^{\mathrm{c}}$ & $0.49 \pm 0.010^{\mathrm{b}}$ & $0.49 \pm 0.010^{\mathrm{c}}$ & $0.44 \pm 0.010^{\mathrm{c}}$ \\
& $\mathbf{S}$ & $0.54 \pm 0.013^{\mathrm{b}}$ & $0.52 \pm 0.012^{\mathrm{b}}$ & $0.55 \pm 0.010^{\mathrm{b}}$ & $0.54 \pm 0.010^{\mathrm{b}}$ \\
& $\mathbf{P}$ & $0.60 \pm 0.010^{\mathrm{a}}$ & $0.58 \pm 0.010^{\mathrm{a}}$ & $0.62 \pm 0.010^{\mathrm{a}}$ & $0.57 \pm 0.010^{\mathrm{a}}$ \\
\hline
\end{tabular}

C, control; S, salt plants; P, propionibacteria; O. r. sh, outer root sheath; I. r. sh, inner root sheath.

In each parameter, means within the same column followed by different letters differed significantly $(\mathrm{P}<0.05)$.

Generally, the wool follicle have evolved a number of interesting features of carbohydrate metabolism including glutaminolysis, aerobic glycolysis, significant activity of the pentose phosphate pathway, and storage and mobilization of glycogen. Presumably, the necessity to continue to produce fibre despite fluctuations in the supply of oxygen and nutrients has reduced in some of these unique features, while others reflect the high level of DNA and protein synthesis occurring in the follicle. However, Todesco et al. (1991) concluded that the amount of anaerobic bacteria, the ratio of anaerobes to aerobes, and the number of bifidobacteria increased significantly during propionate feeding.

Protein is usually the most expensive part of the diet of sheep. Since the rumen synthesize protein from amino acids, the quantity of protein is more important than quality of protein. The distribution of the general proteins as demonstrated by the bromophenol blue stain in wool follicles of the different groups showed that both outer and inner root sheaths of the wool follicles possessed high amounts of proteins (Figs. 6 and 7). In comparison between the experimental groups (Table 2), the (P) group showed the highest significant protein contents in the outer and inner root sheaths of the primary follicles $(0.60 \pm 0.010$ and $0.58 \pm 0.010)$ respectively. The results of the protein contents in the secondary follicle sheaths confirmed this concept and recorded the highest values $(0.62 \pm 0.010$ and $0.57 \pm 0.010)$ of protein contents in the animals had propionibacteria in their diets in both outer and inner root sheaths respectively. 


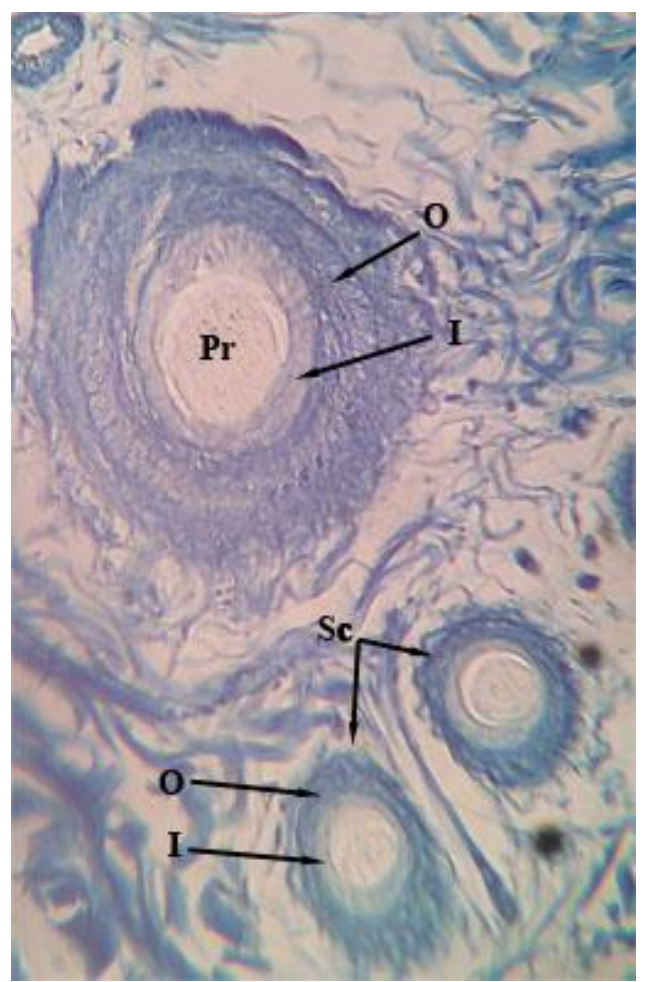

Figure 6. Transverse section in the wool follicles of Barki ewes stained with bromophenol blue showing the distribution of general proteins in the different follicle sheaths. I, inner root sheath; O, outer root sheath; Pr, primary follicle; Sc, secondary follicle (X400)

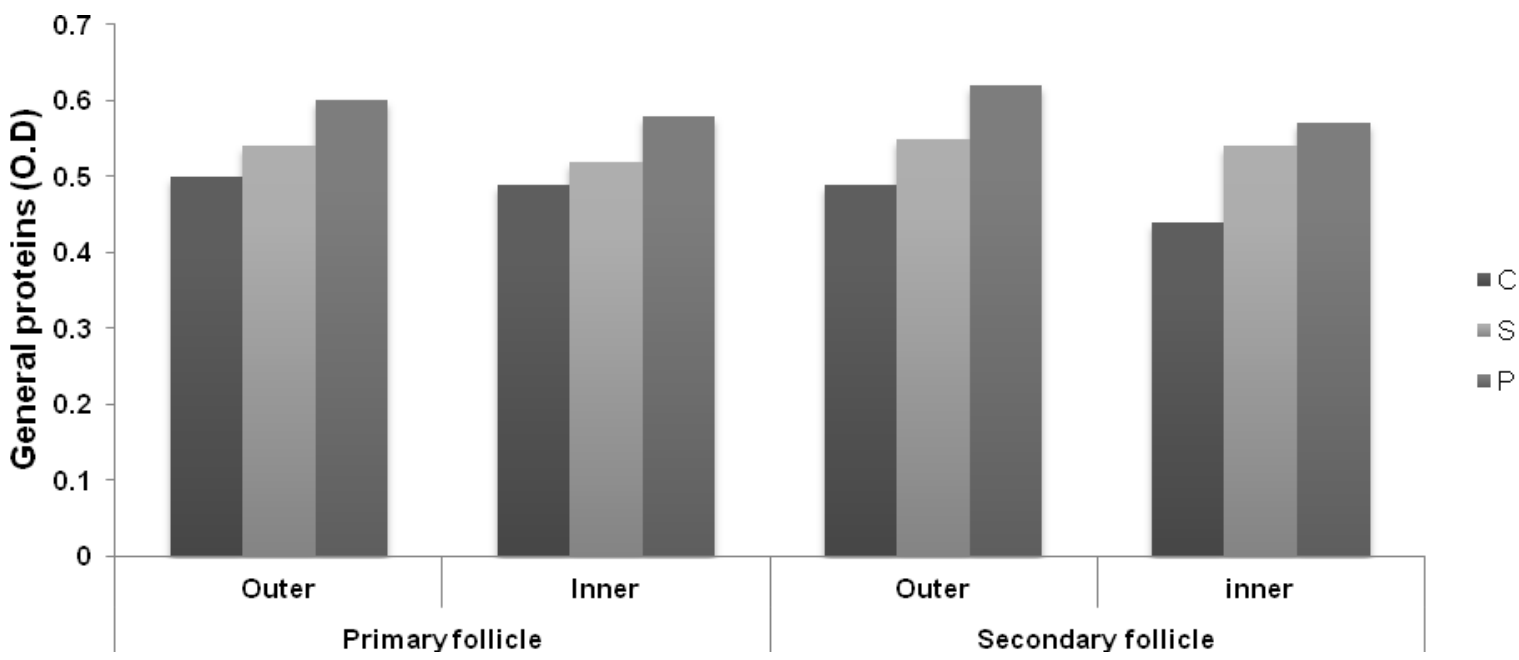

Figure 7. Average optical density values of general proteins in the outer and inner root sheath of both primary and secondary follicles in the skin of Barki ewes under different feeding treatments. C, control; $S$, salt plants; $P$, propionibacteria

Animals fed salt plants in (S) group recorded the intermediate values of the protein content in the outer and inner root sheaths of both primary and secondary follicles $(0.54 \pm 0.013,0.52 \pm 0.012$ and $0.55 \pm 0.010$, $0.54 \pm 0.010)$, respectively. These results reflect the effect of the anti-nutritional factors in the salt plants on the wool follicle activity. Consequently, the decrease in crude protein in these plants might be affected wool production and yield as represented by Helal and Fayed (2013). Also, Morcombe et al. (1994) reported that sheep fed on saltbush pastures had low wool quality and this might be due to the restriction effect of tannins on amino acid and sulphur availability for metabolizable protein synthesis.

The findings in Table (2) approved that the microbial protein synthesis in the rumen and its availability for digestion and absorption in the intestine is most closely related to the intake of digestible energy by the animal than to the protein content of the diet. On another point of view, Sahoo and Soren (2011) stated that although wool growth increased with increasing digestible organic matter intake, its effect is consistent with its probable effect on microbial protein synthesis in the rumen. Thus, it would appear that apparent response in wool growth 
to an increase in organic matter or energy intake is to the increased supply of microbial amino acids reacting the lower gastro intestinal tract. So, in the absence of unfermented or escape dietary protein, it appears that the supply of sulphur-amino acids from microbial protein is the primary factor limiting wool growth. In addition, supplementation of probiotic to the diet can enhanced the consumption of feed and absorption of nutrients (Whitley et al., 2009) and consequently improved animals' performance.

Table (3) and figure (8) reflect these concepts by showing the mean diameters of fibres produced from both primary and secondary follicles measured from histological preparation of different experimental groups of sheep. The mean fibre diameters decreased significantly in the $(\mathrm{S})$ group than in the $(\mathrm{C})$ group being $57.79 \pm 2.91 \mu \mathrm{m}$ vs. $49.83 \pm 3.33 \mu \mathrm{m}$ in the primary follicles and $22.54 \pm 1.00 \mu \mathrm{m}$ vs. $16.98 \pm 0.77$ $\mu \mathrm{m}$ in the secondary follicles. In agreement, Hunter et al. (1990) reported a reduction in fibre diameter of up to $40 \%$ in nutritional stressed animals. Also, Helal and Fayed (2013) stated that using Halophytes in animal feeding significantly depressed the wool fibre characteristics. Moreover, feeding sheep on fresh Halophytes caused reduction in $\mathrm{N}$ digestibility and decreased wool growth and yield, as well as sulphur absorption (Prichard et al., 1988).
The supplementation with Propionibacteria in $(\mathrm{P})$ group of sheep recorded a significant increase in the diameters of fibres produced from the secondary follicles $(24.57 \pm 0.88 \mu \mathrm{m})$ exceeded the control group (Table 3) while in primary follicles, the changes in fibre diameter were unnoticed. Confirming this, Khalid et al. (2011) found that addition of probiotic in the diet of lambs has been reported to improve growth performance and feed conversion. Also, Abdel-Salam et al. (2014) showed that the synbiotic supplementation had highly significant effect on wool diameter.

Table 3. Mean diameter values $( \pm$ SE) of fibres produced from both primary and secondary wool follicles in Barki ewes under different feeding treatments

\begin{tabular}{ccc}
\hline $\begin{array}{c}\text { Feed } \\
\text { treatments }\end{array}$ & Primary fibres & $\begin{array}{c}\text { Secondary } \\
\text { fibres }\end{array}$ \\
\hline $\mathbf{C}$ & $57.79 \pm 2.91^{\mathrm{a}}$ & $22.54 \pm 1.00^{\mathrm{ab}}$ \\
$\mathbf{S}$ & $49.83 \pm 3.33^{\mathrm{b}}$ & $16.98 \pm 0.77^{\mathrm{b}}$ \\
$\mathbf{P}$ & $48.65 \pm 2.97^{\mathrm{b}}$ & $24.57 \pm 0.88^{\mathrm{a}}$ \\
\hline
\end{tabular}

C, control; S, salt plants; P, propionibacteria.

Means followed by different letters differed significantly $(\mathrm{P}<0.05)$

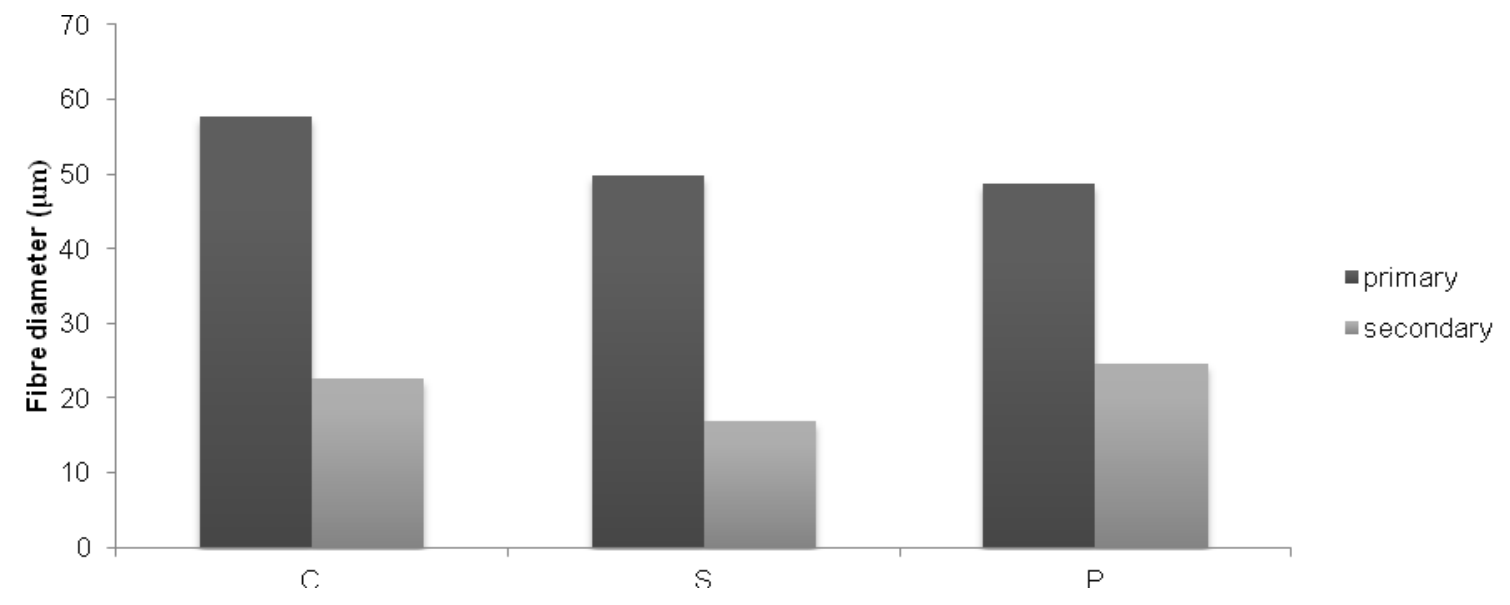

Figure 8. Mean diameters of wool fibres produced from primary and secondary follicles in the skin of Barki ewes under different feeding treatments. $C$, control; $S$, salt plants; $P$, propionibacteria

The various nutritional levels in the different experimental groups had no significant effect on the medulla thickness of the wool fibres (Table 4).

Table 4. Mean values $( \pm$ SE) of medulla thickness in wool fibres of Barki ewes under different feeding treatments

\begin{tabular}{cc}
\hline Feed treatments & Medulla thickness \\
\hline $\mathbf{C}$ & $39.83 \pm 1.87^{\mathrm{a}}$ \\
$\mathbf{S}$ & $34.85 \pm 3.11^{\mathrm{a}}$ \\
$\mathbf{P}$ & $39.78 \pm 2.62^{\mathrm{a}}$ \\
\hline
\end{tabular}

C, control; S, salt plants; $\mathrm{P}$, propionibacteria.

Means followed by different letters differed significantly $(\mathrm{P}<0.05)$
Mc-Gregor (1984) reported that a lower level of nutrition was associated with an increased medullated fibre content of the fleece, although this not found by latter studies by Bigham et al. (1990). In a review of factors influencing the degree of medullation, Lupton et al. (1991) concluded that nutrition has little if any effect on the incidence of this undesirable characteristic. This was in agreement with the results on sheep in the present study as shown by Table (4). Also, Scobie et al. (1998) concluded that the proportion of medullation in Romney wool could vary independently than average fibre diameter.

Studies on the wool fibres in the present study was coincident with the previous results throughout Table (5) which indicated that group (P) $(27.97 \pm 1.92$ 
$\mu \mathrm{m})$ was slightly higher than the control group $(27.36 \pm 1.92 \mu \mathrm{m})$ in fibre diameter and both of the two groups were higher than group (S) $(24.32 \pm 1.92$ $\mu \mathrm{m})$. This was attributed to the increased coarse and kemp fibre percentages in $(\mathrm{P})$ group which given propionibacteria while ewes fed salt plants showed the lowest percent. Table (5) also showed that staple length was longer in group (P) and control group than in (S) group $(4.22 \pm 0.44,3.95 \pm 0.44$ vs. $3.60 \pm 0.44 \mathrm{~cm})$ respectively.

Table 5. Mean values $( \pm$ SE) of wool weight, clean wool yield $\%$, fibre diameter, staple length and fibre type ratio (\%) of Barki ewes under different feeding treatments

\begin{tabular}{lccc}
\hline Wool characteristics & $\mathbf{C}$ & $\mathbf{S}$ & $\mathbf{P}$ \\
\hline Wool weight $\left(\mathbf{g m} / \mathbf{c m}^{\mathbf{2}}\right)$ & $0.020+0.005^{\mathrm{a}}$ & $0.022+0.005^{\mathrm{a}}$ & $0.034+0.005^{\mathrm{a}}$ \\
Clean wool Yield \% & $70.64+4.83^{\mathrm{a}}$ & $71.83+4.83^{\mathrm{a}}$ & $75.93+4.83^{\mathrm{a}}$ \\
Fibre diameter $(\boldsymbol{\mu m})$ & $27.36+1.92^{\mathrm{a}}$ & $24.32+1.92^{\mathrm{a}}$ & $27.97+1.92^{\mathrm{a}}$ \\
Staple length $(\mathbf{c m})$ & $3.95+0.44^{\mathrm{a}}$ & $3.60+0.44^{\mathrm{a}}$ & $4.22+0.44^{\mathrm{a}}$ \\
Fine fibres \% & $57.86+6.92^{\mathrm{a}}$ & $67.33+6.92^{\mathrm{a}}$ & $54.54+6.92^{\mathrm{a}}$ \\
Coarse fibres \% & $33.17+4.25^{\mathrm{a}}$ & $26.02+4.25^{\mathrm{a}}$ & $34.16+4.25^{\mathrm{a}}$ \\
Kemp fibres \% & $8.97+3.12^{\mathrm{a}}$ & $6.64+3.12^{\mathrm{a}}$ & $11.30+3.12^{\mathrm{a}}$ \\
\hline
\end{tabular}

C, control; S, salt plants; P, propionibacteria.

Means followed by different letters differed significantly $(\mathrm{P}<0.05)$

Wool was defined as protein fibre affected significantly by both feed quality and quantity. The decrease in digestible crude protein in animals fed salt plants in (S) group compared with those of (P) group might be affected greasy wool production represented by wool weight $(\mathrm{gm} / \mathrm{cm} 2)$ and yield $\%$ (Table 5). Generally, the increase in wool production in group (P) is a result of increasing both fibre diameter and staple length and this was in accordance with (Abdel-Salam et al., 2014).

The challenge of applied nutrition in vivo would appear to be to create conditions in the digestive tract and post-absorptively to deliver such concentrations to the cells and extracellular components of the individual follicle.

The ingredients of probiotics are mainly lactic acid bacteria (Lactobacillus acidophilus and Bifidobacteriumbifidum) which proved to enhance the functions of the lower gut (Rafter, 2003). Additionally, there might have a synergistic effect between these bacteria and rumen microorganisms to enhance their functions in rumen absorption. Also, some lactic acid bacteria have been shown to increase colonic NADPH- cytochrome P-450 reductase activity (Pool-Zobel, 2005) and glutathione Stransferase levels (Challa et al., 1997). Obviously, these enzymes, which improved in several metabolic processes including increased absorption and utilization of nutrition, might enhance such physiological functions in the treated animals.

Several areas were highlighted in which more information is needed regarding the effects of nutrition, and other environmental factors, on the quantity and quality of wool produced by Barki sheep.

Nutritional augmentation of wool production can never be economical in real terms, although it significantly affects wool yield and quality. Moreover, any supplemental nutrition has got concurrent bearing on growth and performance and these in totality has influenced economic return from sheep production through narrower input: output ratio and increased profitability.

\section{ACKNOWLEDGEMENT}

This work was made as a part of project "Adaptation to climatic change in WANA marginal environments through sustainable crop and livestock diversification" which was financially supported by the International Center for Biosaline Agriculture (ICBA), Dubai, UAE.

\section{REFERENCES}

Abdelaziz, N.M., H.M. El-Gabbas, M.M. Abdelsalam, and E.M. Al-Bitar, 2000. The responses of some factors and nutritional stresses on objective and subjective wool traits of some Egyptian breeds of sheep.Proc. $3^{\text {rd }}$ All Africa Conf. Anim. Agric. and $11^{\text {th }}$ Conf. Egyptian Soc. Animal Proc. Alexandria, Egypt. 6-9 November, 2000:729-736.

Abdel-Salam, A.M., M.M. Zeitoun, and M.M. Abdelsalam, 2014. Effect of Synbiotic Supplementation on Growth Performance, Blood Metabolites, Insulin and Testosterone and Wool Traits of Growing Lambs. Journal of Biological Sciences Volume 14, Number 4, 292-298.

Aleman, M.M., D.R. Stein, D.T. Allen, E.K.V. Perry, T.G. Lehloenya, K.J. Rehberger, D.A. Mertz Jones and L.J. Spicer, 2007. Effects of feeding two levels of Propionibacteria to dairy cows on plasma hormones and metabolites. J Dairy Res. 2007 May; 74(2):146-153.

Al-Owaimer, A. N., A. M. El-Waziry, M. Koohmaraie and S. M. Zahran, 2011. The Use of Ground Date Pits and Atriplexhalimus as Alternative Feeds for Sheep.Australian Journal of Basic \& Applied Sciences; Vol. 5 Issue 5, p1154.

Al-Sobayil, K.A., M.M. Zeitoun, M.H. Khalil and A.M. Abdel-Salam, 2008. Effect of oral administration of functional synbiotic syrup on libido, semen characteristics, serum testosterone 
and liver and kidney function of goat's bucks. Asian J. Biol. Sci., 1: 11-18.

Antunovic, Z., Marcela Speranda, D. Amidzic, V. Seric, Z. Steiner, N. D. Cinovic and F. Boli, 2006. Probiotic application in lambs nutrition. Krmiva 48, 4; 175-180.

Arieli, A., E. Naim, R. W. Benjamin and D. Pasternak, 1989.The effect of feeding saltbush and sodium chloride on energy metabolism in sheep.Animal Production. Volume (49) Issue (3) Pp: 451-457.

Barker, J.R., 1958. Principles of Biological Technique.London, Methuen, New York, John Wiley, Bancroft. J. D.

Bigham, M. L., M. Bown and G.B. Nicoll, 1990.The manipulation of kemp and medullation in the Mohair Fleece by breeding and management.Proceeding $8^{\text {th }}$ research conference, New Zealand. (7). Pp. 277-283.

Blache, D, M.J. Grandison, D.G. Masters, R.A. Dynes, M.A. Blackberry and G.B. Martin, 2007. Relationships between metabolic endocrine systems and voluntary feed intake in Merino sheep fed a high salt diet. Aust. J. Exp. Agr. 47(5): 544-550.

Challa, A., D. R. Rao, C. B. Chawan and L. Shackelford, 1997. Bifidobacteriumlongum and lactulose suppress azoxymethane-induced colonic aberrant crypt foci in rats. Carcinogenesis. 18 (3):517-521.

Chapman, R. E.,1960. In The Biology of the Fleece, edited by A. S. Fraser, and B. F. Short, Animal Research Laboratories Technical Paper NO.3. CSIRO, Australia.

Chapman, D.M., 1975. Dichromation of bromophenol blue with an improvement in the mercuric bromophenol blue technique for protein. Stain Technology., 50: 25-30.

Cottle, D.J., 1988. Effects of defaunation of the rumen and supplementation with amino acids on the wool production of housed Saxon Merinos. 2. Methionine and protected Methionine. Australian Journal of Experimental Agriculture 28(2) 179185.

Drury, R.A.B. and E.A. Wallington, 1980.Carleton's Histological Technique. $5^{\text {th }}$ Ed. Oxford University Press. Oxford, UK., 520.

El-Shaer, H. M., 2006. Halophytes as cash crops for animal feeds in arid and semi arid regions. In: M Ozturk, Y Waisel, M. A. Khan, G Gork (eds): Biosaline agriculture\& high salinity Tolerance in plant. Birkhauser, Basel, 117-128.

Francisco, C.C., C.S. Chamberlain; D.N. Waldner, R.P. Wettemann and L. J. Spicer, 2002. Propionibacteria fed to dairy cows: Effects on energy balance, plasma metabolites and hormones, and reproduction. J Dairy Sci. Jul; 85(7):1738-51.

Ghorbani, G. R., D. P. Morgavi, K. A. Beauchemin and J. A. Z. Leedle, 2002. Effects of bacterial direct-fed microbial on ruminal fermentation, blood variables, and the microbial populations of feedlot cattle. J. Anim. Sci. 80:1977-1980.

Hanafy, M. A., A. A. Fahmy, M.S. Fargaly and Afaf A. El-Sheref, 2007. Effect of using some fodder plants in diets on goats performance under desert conditions of Sinai. Egyptian J. Nut.And Feeds. 10(1): 151-163.

Helal, A. and A. M. Fayed, 2013. Wool characteristics of sheep fed on halophyte plants ensiled by some biological treatments. Proceedings Book of $4^{\text {th }}$ International Scientific Conference on Small Ruminant Development. Egyptian Journal of Sheep and Goat Sciences, Vol. 8 (1), P: 131-139.

Hunter, L., T.B. Van Wyk, P.J. De Wet, P.D. Grobbelaar; P.S. Pretorius; J. Morris and W. Leeuner, 1990 .the effect of nutritional and lambing stress on wool fibre and processing characteristics. Wool technology and sheep breeding.Sep. 1990/ Oct., 1990/ and Dec., 1990/ Jan., 1991), 89-91d.

Kearl, L. C., 1982. Nutrient Requirements of Ruminants in Developing Countricces. Utah. Agric. Exp. Utah State University. Logan, Utah.

Khalid, M.F., M.A. Shahzad, M. Sarwar, A.U. Rehman, M. Sharif, and N. Mukhtar, 2011. Probiotics and lamb performance: A review. Afr. J. Agric. Res., 6: 5198-5203.

Lupton, C. J., F. A. Pfeiffer, and N. E. Blakeman, 1991. Medullation in mohair. Small Ruminant Res. 5:357-365.

Mahgoub, A.E.S., M.F.A. Fahmy and Y.S. Ghanem, 1974. A histological study of the skin of some breeds of sheep.1 Layers of the skin. J. Fac. Vet. Med., Cairo Univ., 22(51): 303-307.

Mannus, T. G. and J. M. Boda, 1965. Control of insulin secretion in sheep, the effect of volatile fatty acids and glucose. Physiologist; 8:227-9.

McDonald, P., R.A. Edwards, j.F.D. Greenhalgh and C.A. Morgan, 1987. Animal Nutrition .5th ed. Longman Singapore, 202 p.

Mc-Gregor, B.A., 1984. Growth and fleece production of Angora withers grazing animal pastures. Proceeding of the Australian society of animal production. 15: 715 .

Mc-Manus, J.P.A. and J.E. Cason, 1950. Carbohydrate histochemistry studied by acetylation techniques periodic acid method. J. Exp. Med., 91: 651.

Montagna, W and R.A. Ellis, 1958. The biology of hair growth.Academic press. New York. Pp.65.

Montegana, W. (1956).T he structure and function of the skin.Academic press, New York.Pp. 174.

Morcombe, P. W.; G. Young and K.A. Boase, 1994.short term, high density grazing of a saltbush plantation reduces wool staple strength in weathers. Proceeding of the Australian Society of animal production Vol, 20, Pp. 313-316.

Pool.Zobel, B., 2005. Insulin-type fructans and reduction in colon cancer risk: Reviews of experimental and human data. Br. J. Nutr., 92 (1): 73-90. 
Pritchrd, D.A., D.C. Stocks, B.M. O'sullivan, P.R. Martin, I.S. Hurwood and P.K. O'rourke, 1988. The effect of polyethylene glycol (PEG) on wool growth and liveweight of sheep consuming a mulga (ACACIA ANEURA) diet. Proc. Aust. Soc. Anim. Prod. Vol. 17.

Rafat, S.A. and D. Shodja, 2004. The effect of feeding levels characteristics of fibres of Raeini Cashmere goats. Livestock Res. Rural Dev., Pp: 16.

Rafter, J., 2003. Probiotics and colon cancer. Beat pract. Res.Cl. Ga., 17(5): 849-859.

Reynolds, C.K., P.C. Aikman, B. Lupoli, D.J. Humphries and D.E. Beever, 2003. Splanchnic metabolism of dairy cows during the transition from late gestation through early lactation.J. Dairy Sci. Apr; 86(4):1201-17.

Russell, J.B. and D.B. Wilson, 1996. Why are ruminal cellulolytic bacteria unable to digest cellulose at low pH? J. Dairy Sci. 79(8):1503-9.

Sahoo, A.and N.M. Soren, 2011. Nutrition for Wool Production.Webmedcentral-Review articles, 2(10).

Sarwar, M., N. Mukhtar, M.A. Shehzad and M. Nisa, 2010. Traditional versus high input feeding system: Impact on nutrients intake, blood dynamics, hormonal profile, weight gain and economics in growing lambs. Egy. J. Sheep Goat Sci., 5: 127-145.

SAS, 2004. Statistical Analysis System Institute, SAS User's Guide Statistics, SAS Institute Inc., Cary, NC.

Scobie, D. R., A. R. Bray, and N. C. Merrick, 1998. Medullation and average fibre diameter vary independently in the wool of Romney sheep. New Zealand Journal of Agricultural Research.Volume 41, Issue 1.

Stein, D.R., D.T. Allen, E.B. Perry, J.C. Bruner, K.W. Gates, T.G. Rehberger, K. Mertz, D. Jones, and L.J. Spicer, 2006. Effects of feeding propionibacteria to dairy cows on milk yield, milk components, and reproduction.Journal of Dairy Science 89, 111-125.

Todesco, T., A.V. Rao, O. Bosello and D.J. Jenkins, 1991. Propionate lowers blood glucose and alters lipid metabolism in healthy subjects. Am. J. Clin. Nutr. Nov; 54(5):860-5.

Vedamuthu, E. R. and G. W. Reinbold, 1967. The use of candleoats jar incubation for the enumeration, characterization and taxonomic study of propionibacteria. Milchwissenchaft, 22: 428-431.

Warner, B. E. and T. Casson, 1992.Performance of sheep grazing salt tolerant forages on revegetated salt land. Aust. Soc. Anim. Prod. Vol. 19.

Whitly, N.C., D. Cazac, B. T. Rude, O. Jackson, D. Brien and S. Parveen, 2009. Use of commercial propiotic supplement in meat goat, J. of Anim. Sci. 87:723-728.

Yoon, I. K. and M. D. Stern, 1995. Influence of direct-fed microbials on ruminal fermentation and performance of ruminants: a review. Australian. J. Anim. Sci. 8:533-555.

Zen , 2012. (Blue edition) Carl Zeiss MicroImaging GmbH. 07740 Jena, Deutschland, BioSciences | Location Göttingen, P.O.B. 4041, 37030 Göttingen, Germany.

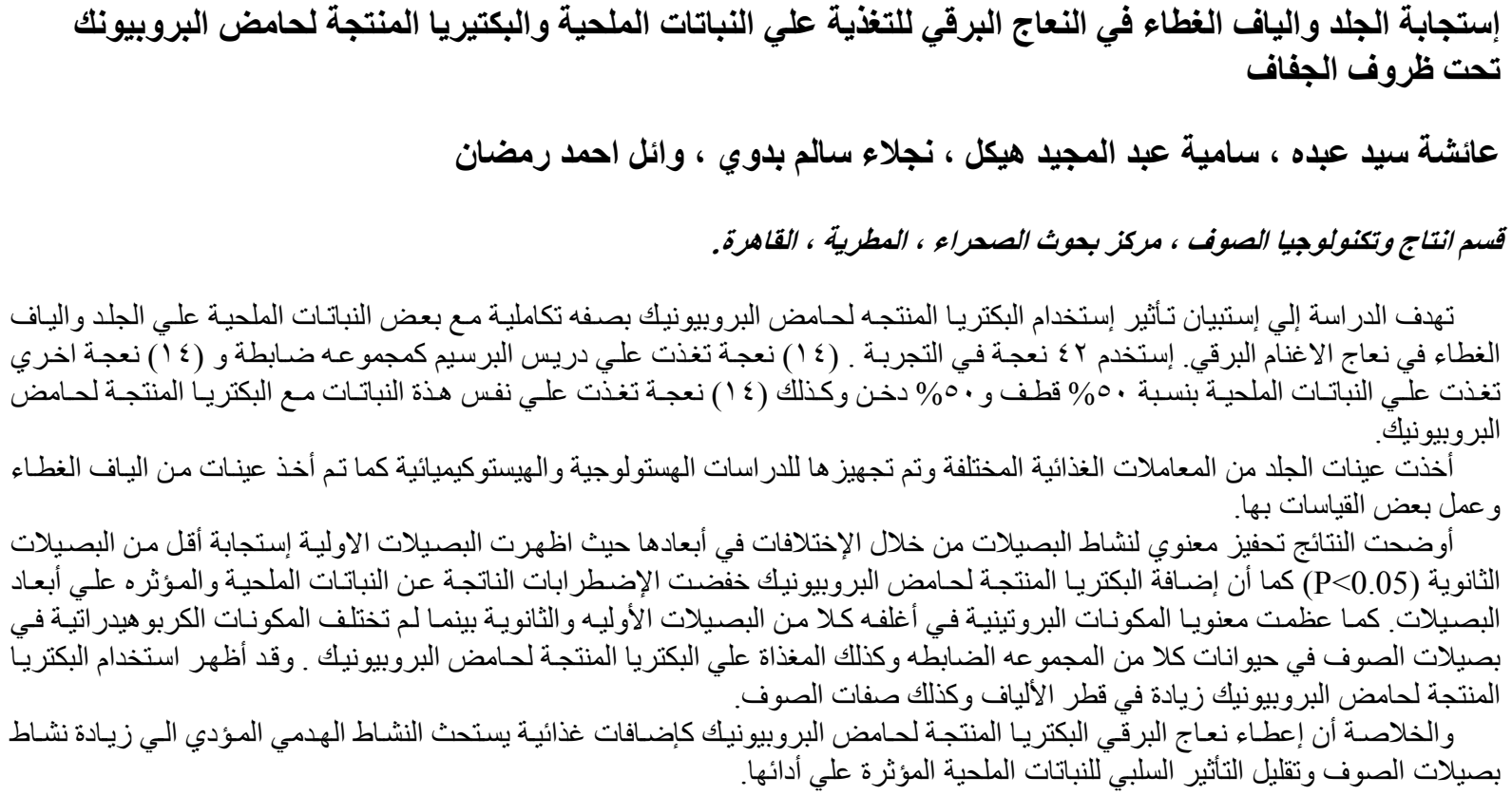

